\title{
Registered report: Widespread potential for growth factor-driven resistance to anticancer kinase inhibitors
}

\author{
Edward Greenfield', Erin Griner², Reproducibility Project: Cancer Biology*† \\ ${ }^{1}$ Monoclonal Antibody Core Facility, Dana-Farber Cancer Institute, Boston, United \\ States; ${ }^{2}$ University of Virginia, Charlottesville, United States
}

\section{REPRODUCIBILITY CANCEJECT} CANCER BIOLOGY

*For correspondence: fraser@ scienceexchange.com

Group author details ${ }^{\dagger}$ Reproducibility Project: Cancer Biology

See page 16

Competing interests: See page 16

Funding: See page 16

Received: 16 July 2014

Accepted: 28 September 2014

Published: 10 December 2014

Reviewing editor: Joan Massagué, Memorial SloanKettering Cancer Center, United States

(c) Copyright Greenfield et al. This article is distributed under the terms of the Creative

Commons Attribution License, which permits unrestricted use and redistribution provided that the original author and source are credited.
Abstract The Reproducibility Project: Cancer Biology seeks to address growing concerns about reproducibility in scientific research by conducting replications of 50 papers in the field of cancer biology published between 2010 and 2012. This Registered Report describes the proposed replication plan of key experiments from 'Widespread potential for growth-factor-driven resistance to anticancer kinase inhibitors' by Wilson and colleagues, published in Nature in 2012 (Wilson et al., 2012). The experiments that will be replicated are those reported in Figure 2B and $C$. In these experiments, Wilson and colleagues show that sensitivity to receptor tyrosine kinase (RTK) inhibitors can be bypassed by various ligands through reactivation of downstream signaling pathways (Figure 2A; Wilson et al., 2012), and that blocking the receptors for these bypassing ligands abrogates their ability to block sensitivity to the original RTK inhibitor (Figure 2C; Wilson et al., 2012). The Reproducibility Project: Cancer Biology is a collaboration between the Center for Open Science and Science Exchange, and the results of the replications will be published by eLife. DOI: 10.7554/eLife.04037.001

\section{Introduction}

A recurring theme in treatment of cancer is the acquisition of drug resistance. The effectiveness of therapies targeting specific mutations in receptor tyrosine kinases (RTKs) is limited by the acquisition of resistance to the drugs over the course of treatment (Mok et al., 2009; Camidge et al., 2014). Resistance can be acquired through new mutations that block the action of the RTK inhibitors or their uptake and/or genetic amplification of downstream target genes of the RTK (Chen and Fu, 2011; Garrett and Arteaga, 2011; Sequist et al., 2011; Gainor and Shaw, 2013; Yang, 2013). Several studies, including this work by Wilson and colleagues, elucidated another mechanism for this acquisition of resistance: the engagement of parallel RTK signaling pathways that converge on common downstream survival signals via signals from the tumor microenvironment. In this study, Wilson and colleagues examined several cancer cell lines for ligand-mediated drug resistance (Wilson et al., 2012).

In Figure 2B/C, Wilson and colleagues demonstrated that resistance to primary kinase inhibitor treatment can be induced by the addition of rescuing ligands that activate the PI(3)K-AKT and MAPK pro-survival signaling pathways. This resistance can be overcome with the addition of an appropriate secondary kinase inhibitor. Three different cancer cell line models were used to demonstrate this phenomenon. Treatment of A204 (a PDGFR amplified rhabdomyosarcoma cell line) with the ligand FGF activated pFRS2 and pERK, inducing resistance to sunitinib. The addition of a secondary kinase inhibitor, PD173074, blocked FGF-induced pFRS2 and pERK activation, restoring sensitivity to sunitinib. The treatment of M14 (a BRAF-mutated melanoma cell line) with the ligand NRG1 activated pHER3 and pAKT, inducing partial resistance to PLX4032. The addition of a secondary kinase inhibitor, lapatinib, blocked NRG1-induced pHER3 and pAKT activation, restoring sensitivity to PLX4032. Treatment of KHM-3S (an EGFR-mutated small cell lung cancer cell line) with the ligand HGF 
activated pMET and pERK, inducing resistance to Erlotinib. The addition of a secondary kinase inhibitor, crizotinib, blocked HGF-induced pMET and pERK activation, restoring sensitivity to erlotinib.

The cell viability assays examining drug sensitivity and the Western blots examining levels of phosphorylated kinases in Figures $2 \mathrm{~B}$ and 2C, respectively, are the key experiments that demonstrate that growth factor ligands can reactivate downstream signaling components important for cancer cell survival, causing resistance to anticancer kinase inhibitors (Wilson et al., 2012). These experiments are replicated in Protocols 1 and 2 .

Two studies published around the same time as the work of Wilson and colleagues also support the proposed mechanism of acquired resistance to RTK inhibition by signaling from the tumor microenvironment. Straussman and colleagues demonstrated that HGF signaling derived from the tumor microenvironment could bypass EGFR inhibition by activation of MET signaling (Straussman et al., 2012, also included for replication in the Reproducibility Project: Cancer Biology), and Harbinski and colleagues, in an approach similar to Wilson and colleagues, showed that multiple growth factor ligands could 'bypass' inhibitor-targeted RTKs (Harbinski et al., 2012).

Since the publication of Wilson and colleagues' work, several publications have reported similar results to those being replicated in Protocols 1 and 2. Similar to the experiments with A204 cells above, Welti and colleagues demonstrated that FGF ligands could induce resistance to sunitinib, which could be reversed by the addition of PD173074 (Welti et al., 2011). These experiments were performed in HUVEC cells, whereas A204 cells were used in the study being replicated. Similar to the experiments on M14 cells above, Montero-Conde and colleagues showed that NRG1 ligand could activate pHER3 and pAKT in the presence of PLX4032, and this activation could be reversed by the addition of lapatinib (Montero-Conde et al., 2013). These experiments were performed in $8505 \mathrm{C}$ cells, whereas M14 cells were used in the study being replicated. Similar to the experiments performed on KHM-S3 cells above, several groups have demonstrated that HGF ligand can induce resistance to erlotinib and that this resistance can be reversed by the addition of crizotinib (Nakagawa et al., 2012; Nakade et al., 2014). These experiments were performed in PC-9 and HCC827 cells, whereas KHM-3S cells were used in the study being replicated.

\section{Materials and methods}

Unless otherwise noted, all protocol information was derived from the original paper, references from the original paper, or information obtained directly from the authors. An asterisk $\left(^{\star}\right)$ indicates data or information provided by the Reproducibility Project: Cancer Biology core team. A hashtag (\#) indicates information provided by the replicating lab.

\section{Protocol 1: Cell viability assays}

This protocol describes cell viability assays to determine the $\mathrm{IC}_{50}$ values of three cancer cell lines treated with primary kinase inhibitor alone, primary kinase inhibitor in combination with rescuing ligand, and primary kinase inhibitor in triple combination with rescuing ligand and a drug targeting the rescuing ligand's receptor tyrosine kinase (RTK) (termed the secondary kinase inhibitor) (Figure 2B).

\section{Sampling}

- The original data presented is qualitative, and the authors were unable to share the raw data values with the RP:CB core team. This prevents power calculations being performed a priori to determine the sample size (number of biological replicates). In order to determine an appropriate number of replicates to perform initially, we have estimated the sample sizes required based on a range of potential variance. We will also determine the sample size post hoc as described in Power Calculations.

\section{Please see Power Calculations for details.}

- Each experiment has three cohorts. In each cohort, a dilution series of the primary kinase inhibitor $\left(10^{-4}, 10^{-3}, 10^{-2}, 10^{-1}, 10^{0}\right.$, and $\left.10^{1} \mu \mathrm{M}\right)$ is run three times; once alone, once with the rescuing ligand, and once with both the rescuing ligand and the secondary kinase inhibitor. The effect of the secondary kinase inhibitor alone will also be assessed. Each condition will be run in triplicate.

1. Cohort 1: A204 cell line.

- Media only [additional].

- Vehicle control. 
- $0.001 \mu \mathrm{M}-10 \mu \mathrm{M}$ sunitinib + no ligand.

- $0.001 \mu \mathrm{M}-10 \mu \mathrm{M}$ sunitinib + $50 \mathrm{ng} / \mathrm{ml} \mathrm{FGF}$.

- $0.001 \mu \mathrm{M}-10 \mu \mathrm{M}$ sunitinib + 50 ng/ml FGF + $0.5 \mu \mathrm{M}$ PD173074.

- $0.5 \mu \mathrm{M}$ PD173074 + no ligand [additional].

2. Cohort 2: M14 cell line.

- Media only [additional].

- Vehicle control.

- $0.001 \mu \mathrm{M}-10 \mu \mathrm{M}$ PLX4032 + no ligand.

- $0.001 \mu \mathrm{M}-10 \mu \mathrm{M}$ PLX4032 + $50 \mathrm{ng} / \mathrm{ml}$ NRG1.

- $0.001 \mu \mathrm{M}-10 \mu \mathrm{M}$ PLX4032 + $50 \mathrm{ng} / \mathrm{ml}$ NRG1 + $0.5 \mu \mathrm{M}$ lapatinib.

- $0.5 \mu \mathrm{M}$ lapatinib + no ligand [additional].

3. Cohort 3: KHM-3S cell line.

- Media only [additional].

- Vehicle control.

- $0.001 \mu \mathrm{M}-10 \mu \mathrm{M}$ erlotinib + no ligand.

- $0.001 \mu \mathrm{M}-10 \mu \mathrm{M}$ erlotinib + $50 \mathrm{ng} / \mathrm{ml} \mathrm{HGF}$.

- $0.001 \mu \mathrm{M}-10 \mu \mathrm{M}$ erlotinib $+50 \mathrm{ng} / \mathrm{ml} \mathrm{HGF}+0.5 \mu \mathrm{M}$ crizotinib.

- $0.5 \mu \mathrm{M}$ crizotinib + no ligand [additional].

\section{Materials and reagents}

\begin{tabular}{|c|c|c|c|c|}
\hline Reagent & Type & Manufacturer & Catalog \# & Comments \\
\hline 96-well tissue culture plates & Materials & $\begin{array}{l}\text { Corning } \\
\text { (Sigma-Aldrich) }\end{array}$ & CLS3516 & Original unspecified \\
\hline KHM-3S cells & Cells & JCRB Cell Bank & JCRB0138 & $\begin{array}{l}\text { Original source of the } \\
\text { cells unspecified }\end{array}$ \\
\hline A204 & Cells & ATCC & HTB-82 & $\begin{array}{l}\text { Original source of the } \\
\text { cells unspecified }\end{array}$ \\
\hline M14 & Cells & ATCC & HTB-129* & $\begin{array}{l}\text { Original source of the } \\
\text { cells unspecified }\end{array}$ \\
\hline Lapatinib & Drug & LC Laboratories & L-4804 & $\begin{array}{l}\text { Original formulation } \\
\text { unspecified }\end{array}$ \\
\hline Crizotinib & Drug & Sigma-Aldrich & PZ0191 & $\begin{array}{l}\text { Originally from Selleck } \\
\text { Chemicals }\end{array}$ \\
\hline PD173074 & Drug & Sigma-Aldrich & P2499 & $\begin{array}{l}\text { Originally from Tocris } \\
\text { Bioscience }\end{array}$ \\
\hline PLX4032 & Drug & Active Biochem & A-1130 & \\
\hline Sunitinib & Drug & Sigma-Aldrich & PZ0012 & $\begin{array}{l}\text { Originally from Selleck } \\
\text { Chemicals, formulation } \\
\text { unspecified }\end{array}$ \\
\hline Erlotinib & Drug & LC Laboratories & E-4007 & \\
\hline HGF & Ligand & Sigma-Aldrich & H5791 & $\begin{array}{l}\text { Originally obtained } \\
\text { from Peprotech }\end{array}$ \\
\hline FGF-basic & Ligand & Sigma-Aldrich & F0291 & $\begin{array}{l}\text { Originally obtained } \\
\text { from Peprotech }\end{array}$ \\
\hline NRG1- $\beta 1$ & Ligand & Novus Biologicals & H00003084-P01 & $\begin{array}{l}\text { Originally obtained } \\
\text { from R\&D Systems }\end{array}$ \\
\hline RPMI 1640 & Media & Sigma-Aldrich & R8758 & $\begin{array}{l}\text { Originally from } \\
\text { Gibco, formulation } \\
\text { unspecified }\end{array}$ \\
\hline FBS & Reagent & Sigma-Aldrich & F4135 & Originally from Gibco \\
\hline
\end{tabular}

Table 1. Continued on next page 
Table 1. Continued

\begin{tabular}{lllll} 
Reagent & Type & Manufacturer & Catalog \# & Comments \\
\hline Penicillin & Antibiotic & Sigma-Aldrich & P4458 & Original unspecified \\
\hline Streptomycin & Antifungal & Original unspecified \\
\hline Paraformaldehyde & Reagent & Sigma-Aldrich & 158127 & Original unspecified \\
\hline Syto 60 & Reagent & Life Technologies & S11342 & Original unspecified \\
\hline Odyssey scanner & Equipment & LiCOR & & \\
\hline Odyssey application software & Software & LiCOR & &
\end{tabular}

*The breast cancer cell line MDA-MB-435 has been shown to be mislabeled; it is in fact identical to the M14 melanoma cell line (Rae et al., 2007; Chambers, 2009; Holliday and Speirs, 2011).

\section{Procedure}

\section{Notes}

- All cells will be sent for mycoplasma testing and STR profiling.

- Medium for all cell lines: RPMI 1640 supplemented with 10\% FBS, $50 \mathrm{U} / \mathrm{ml}$ penicillin, and 50 $\mathrm{gg} / \mathrm{ml}$ streptomycin.

- Cells maintained at $37^{\circ} \mathrm{C}$ in a humidified atmosphere at $5 \% \mathrm{CO}_{2}$.

1. Seed 3000-5000 cells per well into 96-well plates. For each condition replicate seed 1 well as the media control, 1 well as the vehicle control, 1 well for treatment with the secondary kinase inhibitor alone, and 6 wells per concentration curve $\left(10^{-4}, 10^{-3}, 10^{-2}, 10^{-1}, 10^{\circ}\right.$, and $\left.10^{1} \mu \mathrm{M}\right)$, of which there are three.

a. 6 wells per concentration curve $\times 3$ concentration curves $=18$ wells +3 wells $=21$ wells per cohort.

2. 18-24 hr after seeding treat 3 wells per condition with appropriate treatment (see Sampling).

a. Lab will record the vehicle used to solubilize the drugs.

3. $72 \mathrm{hr}$ after treatment, fix cells in $4 \%$ paraformaldehyde (PFA).

a. Lab will record the PFA incubation time.

4. Stain with Syto 60 according to the manufacturer's recommendations and assay cell number using an Odyssey with Odyssey Application Software.

a. Include empty wells and media only wells.

5. Calculate cell viability by dividing the fluorescence from the drug-treated cells by the fluorescence from the control (vehicle) treated cells. Fit normalized data to a sigmoidal dose-response curve.

a. Also calculate the effect of vehicle by dividing the fluorescence from the control vehicle cells by the fluorescence from the media only treated cells [additional control].

b. Determine the $I_{50}$ values for each curve.

c. Lab will document the software used to fit the data to a sigmoidal dose-response curve and calculate the $\mathrm{IC}_{50}$ values.

6. Repeat independently two additional times.

\section{Deliverables}

- Data to be collected:

1. Raw fluorescence data and calculated cell viability.

2. Semi-logarithmic graph for each condition of primary kinase inhibitor (log) vs normalized cell viability (linear) for each cell line [comparable to Figure 2B].

3. Calculated $I C_{50}$ for each condition. 


\section{Confirmatory analysis plan}

- Statistical analysis of the Replication Data:

1. For each cell line compare the $I_{50}$ of primary kinase inhibitor alone, primary kinase inhibitor + ligand, and primary kinase inhibitor + ligand + secondary kinase inhibitor.

- ANOVA.

- Meta-analysis of original and replication attempt effect sizes:

1. We will plot the replication data (mean and $95 \%$ confidence interval) and will include the original data point, calculated directly from the representative image in Figure 2B, as a single point on the same plot for comparison.

\section{Known differences from the original study}

- We are including two additional control conditions;

1. Media alone.

a. To provide a baseline.

2. Treatment of the cells with the secondary kinase inhibitor alone.

a. To assess any effects, the secondary kinase inhibitor may be independent of the ligand and primary kinase inhibitor.

\section{Provisions for quality control}

- All data obtained from the experiment-raw data, data analysis, control data, and quality control data-will be made publicly available, either in the published manuscript or as an open access dataset available on the Open Science Framework (https://osf.io/h0pnz/).

- Cell lines will be validated by STR profiling and screened for mycoplasma contamination.

- A lab from the Science Exchange network with extensive experience in conducting cell viability assays will perform these experiments.

\section{Protocol 2: Western blot assays}

This protocol describes Western blot assays to determine the levels of activated phosphorylated signaling pathways in three cancer cell lines treated with primary kinase inhibitor alone, primary kinase inhibitor in combination with rescuing ligand, and primary kinase inhibitor in triple combination with rescuing ligand and a drug targeting the rescuing ligand's receptor tyrosine kinase (RTK) (termed the secondary kinase inhibitor) (Figure 2C).

\section{Sampling}

- The original data presented is qualitative. This prevents power calculations being performed a priori to determine the sample size (number of biological replicates). In order to determine an appropriate number of replicates to perform initially, we have estimated the sample sizes required based on a range of potential variance. We will also determine the sample size post hoc as described in Power Calculations.

1. Please see Power Calculations for details.

- Each experiment has three cohorts. Each cohort will consist of cells treated with media alone, with vehicle alone, with the primary kinase inhibitor, with primary kinase inhibitor and the rescuing ligand and with the primary kinase inhibitor, the rescuing ligand and the secondary kinase inhibitor. The effect of the secondary kinase inhibitor alone will also be assessed. Each condition will be run once (i.e., no technical replicates will be performed). 
1. Cohort 1: A204 cell line.

- Media only [additional].

- Vehicle control.

- $1 \mu \mathrm{M}$ sunitinib + no ligand.

- $1 \mu \mathrm{M}$ sunitinib + 50 ng/ml FGF.

- $1 \mu \mathrm{M}$ sunitinib + 50 ng/ml FGF + $0.5 \mu \mathrm{M}$ PD173074.

- $1 \mu \mathrm{M}$ PD173074 + no ligand [additional].

2. Cohort 2: M14 cell line.

- Media only [additional].

- Vehicle control.

- $1 \mu \mathrm{M}$ PLX4032 + no ligand.

- $1 \mu \mathrm{M}$ PLX4032 + 50 ng/ml NRG1.

- $1 \mu \mathrm{M}$ PLX4032 + 50 ng/ml NRG1 + $0.5 \mu \mathrm{M}$ lapatinib.

- $1 \mu \mathrm{M}$ lapatinib + no ligand [additional].

3. Cohort 3: KHM-3S cell line.

- Media only [additional].

- Vehicle control.

- $1 \mu \mathrm{M}$ erlotinib + no ligand.

- $1 \mu \mathrm{M}$ erlotinib + $50 \mathrm{ng} / \mathrm{ml} \mathrm{HGF}$.

- $1 \mu \mathrm{M}$ erlotinib $+50 \mathrm{ng} / \mathrm{ml} \mathrm{HGF}+0.5 \mu \mathrm{M}$ Crizotinib.

- $1 \mu \mathrm{M}$ crizotinib + no ligand [additional].

4. Cohort 4: positive control cell lines.

- For Cohort 1: HL60 cells treated with FGF [additional control].

- For Cohort 2: MCF7 cells treated with NRG1 [additional control].

- For Cohort 3: HEK293 cells treated with HGF [additional control].

a. Treatment of these cell lines with their cognate growth factor ligands will serve as a positive control for ligand activity.

Materials and reagents:

\begin{tabular}{|c|c|c|c|c|}
\hline Reagent & Type & Manufacturer & Catalog \# & Comments \\
\hline $\begin{array}{l}\text { 96-well Tissue culture } \\
\text { plates }\end{array}$ & Materials & $\begin{array}{l}\text { Corning } \\
\text { (Sigma-Aldrich) }\end{array}$ & CLS3596 & Original unspecified \\
\hline 6-well tissue culture plates & Materials & $\begin{array}{l}\text { Corning } \\
\text { (Sigma-Aldrich) }\end{array}$ & CLS3516 & Original unspecified \\
\hline KHM-3S cells & Cells & JCRB Cell Bank & JCRB0138 & $\begin{array}{l}\text { Original source of the cells } \\
\text { unspecified }\end{array}$ \\
\hline A204 cells & Cells & ATCC & HTB-82 & $\begin{array}{l}\text { Original source of the cells } \\
\text { unspecified }\end{array}$ \\
\hline M14 cells & Cells & ATCC & HTB-129 & $\begin{array}{l}\text { Original source of the cells } \\
\text { unspecified }\end{array}$ \\
\hline HL60 cells & Cells & ATCC & CCL-240 & \\
\hline MCF7 cells & Cells & ATCC & HTB-22 & \\
\hline HEK293 cells & Cells & ATCC & CRL-1573 & \\
\hline Lapatinib & Drug & LC Laboratories & L-4804 & $\begin{array}{l}\text { Original formulation } \\
\text { unspecified }\end{array}$ \\
\hline Crizotinib & Drug & Sigma-Aldrich & PZ0191 & $\begin{array}{l}\text { Originally from Selleck } \\
\text { Chemicals }\end{array}$ \\
\hline PD173074 & Drug & Sigma-Aldrich & P2499 & $\begin{array}{l}\text { Originally from Tocris } \\
\text { Bioscience }\end{array}$ \\
\hline
\end{tabular}

Table 2. Continued on next page 
Table 2. Continued

\begin{tabular}{|c|c|c|c|c|}
\hline Reagent & Type & Manufacturer & Catalog \# & Comments \\
\hline PLX4032 & Drug & Active Biochem & A-1130 & \\
\hline Sunitinib & Drug & Sigma-Aldrich & PZ0012 & $\begin{array}{l}\text { Originally from Selleck } \\
\text { Chemicals, formulation } \\
\text { unspecified }\end{array}$ \\
\hline Erlotinib & Drug & LC Laboratories & E-4007 & \\
\hline HGF & Ligand & Sigma-Aldrich & H5791 & $\begin{array}{l}\text { Originally obtained from } \\
\text { Peprotech }\end{array}$ \\
\hline FGF-basic & Ligand & Sigma-Aldrich & F0291 & $\begin{array}{l}\text { Originally obtained from } \\
\text { Peprotech }\end{array}$ \\
\hline NRG1- $\beta 1$ & Ligand & Novus Biologicals & P1426 & $\begin{array}{l}\text { Originally obtained from } \\
\text { R\&D Systems }\end{array}$ \\
\hline RPMI 1640 & Media & Sigma-Aldrich & R8758 & $\begin{array}{l}\text { Originally from Gibco, } \\
\text { formulation unspecified }\end{array}$ \\
\hline FBS & Reagent & Sigma-Aldrich & F4135 & Originally from Gibco \\
\hline Penicillin & Antibiotic & Sigma-Aldrich & P4458 & Original unspecified \\
\hline Streptomycin & Antifungal & & & Original unspecified \\
\hline $\begin{array}{l}\text { Halt protease and } \\
\text { phosphatase cocktail } \\
\text { inhibitor }\end{array}$ & Reagent & Thermo Scientific & 78440 & \\
\hline Image J & Software & $\begin{array}{l}\text { National Institutes } \\
\text { of Health (NIH) }\end{array}$ & N/A & \\
\hline p-PDGFRa & Antibody & Santa Cruz & SC-12911 & 190 kDa \\
\hline PDGFRa & Antibody & Cell Signaling & 5241 & $190 \mathrm{kDa}$ \\
\hline p-AKT S473 & Antibody & Invitrogen & $44-621 \mathrm{G}$ & $65 \mathrm{kDa}$ \\
\hline AKT & Antibody & Cell Signaling & 9272 & $65 \mathrm{kDa}$ \\
\hline p-ERK T202/Y204 & Antibody & Cell Signaling & 9101 & $44,42 \mathrm{kDa}$ \\
\hline ERK & Antibody & Cell Signaling & 9102 & $44,42 \mathrm{kDa}$ \\
\hline pFRS2a Y196 & Antibody & Cell Signaling & 3864 & $85 \mathrm{kDa}$ \\
\hline FRS2 $\alpha$ & Antibody & Santa Cruz & SC-8318 & $85 \mathrm{kDa}$ \\
\hline$\beta$-tubulin & Antibody & Cell Signaling & 2146 & $55 \mathrm{kDa}$ \\
\hline pHER3 Y1289 & Antibody & Cell Signaling & 4791 & $185 \mathrm{kDa}$ \\
\hline HER3 & Antibody & Santa Cruz & SC-285 & $185 \mathrm{kDa}$ \\
\hline$p$-EGFR Y1068 & Antibody & Abcam & ab5644 & $185 \mathrm{kDa}$ \\
\hline EGFR & Antibody & BD Biosciences & 610017 & $185 \mathrm{kDa}$ \\
\hline p-MET Y1234/5 & Antibody & Cell Signaling & 3126 & $145 \mathrm{kDa}$ \\
\hline MET & Antibody & Santa Cruz & SC-10 & $145 \mathrm{kDa}$ \\
\hline Anti-Mouse IgG-HRP & Antibody & $\begin{array}{l}\text { Cell Signaling } \\
\text { Technology }\end{array}$ & $7076 \mathrm{P} 2$ & Original unspecified \\
\hline Anti-Rabbit lgG-HRP & Antibody & $\begin{array}{l}\text { Cell Signaling } \\
\text { Technology }\end{array}$ & 7074P2 & Original unspecified \\
\hline Anti-Goat lgG-HRP & Antibody & $\begin{array}{l}\text { Santa Cruz } \\
\text { Biotechnology }\end{array}$ & sc-2020 & Original unspecified \\
\hline Trypsin-EDTA solution (1X) & Reagent & Sigma-Aldrich & T3924 & Original unspecified \\
\hline $\begin{array}{l}\text { Dulbecco's Phosphate } \\
\text { Buffered Saline }\end{array}$ & Reagent & Sigma-Aldrich & D1408 & Original unspecified \\
\hline $\begin{array}{l}\text { Mini Protean TGX 4-15\% } \\
\text { Tris-Glycine gels; } 15 \text {-well; } \\
15 \mu l\end{array}$ & Reagent & Bio-Rad & $456-1086$ & Original unspecified \\
\hline 2X Laemmli sample buffer & Reagent & Sigma-Aldrich & S3401 & Original unspecified \\
\hline $\begin{array}{l}\text { ECL DualVue Western } \\
\text { Markers ( } 15 \text { to } 150 \mathrm{kDa} \text { ) }\end{array}$ & Reagent & Sigma-Aldrich & GERPN810 & Original unspecified \\
\hline
\end{tabular}

Table 2. Continued on next page 
Table 2. Continued

\begin{tabular}{lllll} 
Reagent & Type & Manufacturer & Catalog \# & Comments \\
\hline $\begin{array}{l}\text { Nitrocellulose membrane; } \\
0.45 \mu \mathrm{m}, 20 \times 20 \mathrm{~cm}\end{array}$ & Reagent & Bio-Rad & $162-0113$ & Original unspecified \\
\hline Ponceau S & Reagent & Sigma-Aldrich & P7170 & Original unspecified \\
\hline $\begin{array}{l}\text { Tris Buffered Saline (TBS); } \\
\text { 10X solution }\end{array}$ & Reagent & Sigma-Aldrich & T5912 & Original unspecified \\
\hline $\begin{array}{l}\text { Tween } 20 \\
\text { Nonfat-Dried Milk }\end{array}$ & Reagent & Sigma-Aldrich & P1379 & Original unspecified \\
\hline $\begin{array}{l}\text { Super Signal West Pico } \\
\text { Substrate }\end{array}$ & Reagent & Sigma-Aldrich & M7409 & Original unspecified \\
\hline
\end{tabular}

\section{Procedure}

\section{Notes}

- All cells will be sent for mycoplasma testing and STR profiling.

- Medium for cell lines: RPMI 1640 supplemented with 10\% FBS, $50 \mathrm{U} / \mathrm{ml}$ penicillin, and $50 \mu \mathrm{g} / \mathrm{ml}$ streptomycin.

1. MCF7 cells and HEK293 cells are maintained in DMEM + 10\% FBS.

- Cells maintained at $37^{\circ} \mathrm{C}$ in a humidified atmosphere at $5 \% \mathrm{CO}_{2}$.

1. Seed cells in plates.

a. Two control and four experimental wells ( 6 wells total) are needed for each cell line in Cohorts 1-3.

i. Lab will determine and record the number of cells seeded and well size used.

b. *For Cohort 4 seed cells as needed into wells of a 6-well plate.

2. $18-24 \mathrm{hr}$ after seeding treat wells in Cohorts $1-3$ with conditions as described in the Sampling section.

a. Lab will determine and record vehicle for preparation of drug solutions.

b. Harvest protein as in Step 5 after $2 \mathrm{hr}$ of treatment.

3. Simultaneously treat cells in Cohort 4 as follows:

a. HL60 cells. Note: This protocol is based on Krejci et al. (2003).

i. Serum starve HL60 cells for $24 \mathrm{hr}$ prior to protein harvesting.

- Serum starve $=$ DMEM + 0\% FBS.

ii. Treat cells for $10 \mathrm{~min}$ with $100 \mathrm{ng} / \mathrm{ml} \mathrm{FGF}$.

iii. Harvest cell lysates as noted in Step 5.

b. MCF7 cells. Note: This protocol is based on Sarup et al. (2008).

i. Serum starve cells for $48 \mathrm{hr}$ prior to protein harvesting.

- Serum starve $=$ DMEM $+0.1 \%$ BSA .

ii. Treat cells with $1 \mathrm{nmol} / \mathrm{INRG} 1$ for $10 \mathrm{~min}$ at $37^{\circ} \mathrm{C}$.

iii. Harvest cell lysates as noted in Step 5 .

c. HEK293 cells. Note: This protocol is based on Wright et al. (2012).

i. Serum starve HEK293 cells for $24 \mathrm{hr}$ prior to protein harvesting.

- Serum starve = DMEM + 0\% FBS

ii. Treat cells with $29 \mathrm{ng} / \mathrm{ml} \mathrm{HGF}$ for $10 \mathrm{~min}$ at $37^{\circ} \mathrm{C}$.

iii. Harvest cell lysates as noted in Step 5. 
4. \#Preparation of cell lysate:

a. Note: from here on, the replicating lab will use their in-house Western blot protocol, as recommended by the original authors.

b. Harvest cells from the tissue culture plate using $1 \times$ trypsin-EDTA.

c. Wash cells with $1 \times$ cold PBS and spin at $1200 \mathrm{rpm}$ for $5 \mathrm{~min}$.

d. Decant the PBS and add lysis buffer to the cell pellet and resuspend well.

e. Incubate at room temperature for $5 \mathrm{~min}$.

f. Spin solution at $13,000 \mathrm{rpm}$ for $30 \mathrm{~min}$ at $4^{\circ} \mathrm{C}$ using a benchtop centrifuge.

g. Collect the lysate/protein sample and store at $-20^{\circ} \mathrm{C}$ or $-80^{\circ} \mathrm{C}$ for later use.

5. "SDS-PAGE separation:

a. Prepare the lysate sample by adding SDS reducing loading dye to $\sim 25-30 \mu \mathrm{g}$ of protein sample and boiling at $95^{\circ} \mathrm{C}-100^{\circ} \mathrm{C}$ for $5 \mathrm{~min}$.

i. Lab will record exact amount of protein loaded and provide data from determining protein concentration.

b. Let samples cool on ice and quick-spin the tubes to collect any droplets on the cap of the tube.

c. Prepare the gel for sample loading-insert the gel in the gel box with $1 \times$ running buffer and ensure there is no leak.

i. Based on the expected MWs of the targets, lab will determine the optimal percentage gel to use.

d. Load $16 \mu$ l of sample $(25-30 \mu \mathrm{g} /$ lane $)$ in each well of the Tris-glycine gel.

e. Run the sample at $175 \mathrm{~V}$ for $25 \mathrm{~min}$.

$f$. Remove the gel from the cassette and rinse with water.

6. "Transfer and blocking:

a. Transfer protein on the gel to a nitrocellulose membrane for $1 \mathrm{hr}$ at $12 \mathrm{~V}$ using a semi-dry transfer apparatus, $1 \times$ transfer buffer, and blotting sheets.

b. Verify the efficiency of the transfer by Ponceau staining of the membrane.

i. Lab will record an image of the Ponceau-stained membrane.

c. Incubate the blots in 5\% non-fat skim milk for $1 \mathrm{hr}$ at room temperature.

7. "Antibody probing:

a. Dilute the primary antibodies according to the manufacturer's recommendations, as suggested by the original authors.

i. If the manufacturer recommends a range of dilutions, lab will use a dilution in the middle of the recommended dilution range.

ii. A204:

- p-PDGFRa.

- PDGFRa.

- p-AKT S473.

- AKT.

- $p$-ERK T202/Y204.

- ERK.

- pFRS2a Y196.

- FRS2a.

- $\beta$-tubulin [additional control].

A. Loading control.

iii. M14:

- pHER3 Y1289.

- HER3. 
- $\quad$-AKT S473.

- AKT.

- $p$-ERK T202/Y204.

- ERK.

- $\beta$-tubulin [additional control].

A. Loading control.

iv. KHM-3S:

- p-EGFR Y1068.

- EGFR.

- p-AKT S473.

- AKT.

- p-ERK T202/Y204.

- ERK.

- $\mathrm{p}-\mathrm{MET}$ Y1234/5.

- MET.

- $\beta$-tubulin [additional control].
A. Loading control.

v. HL60:

- pERK T202/Y204.

- ERK.

- $\beta$-tubulin [additional control].

A. Loading control.

vi. MCF7:

- pHER3.

- HER3.

- $\beta$-tubulin [additional control].

A. Loading control.

vii. HEK293:

- PMET.

- MET.

- $\beta$-tubulin [additional control].

A. Loading control.

b. Add the antibody solutions to the membranes and incubate them for $12-16 \mathrm{hr}$ at $4{ }^{\circ} \mathrm{C}$.

c. Wash the blots with Tris-buffered saline (TBS) and with $0.5 \%$ Tween-20 three times for 10 min each.

d. Dilute HRP-secondary antibody in $5 \%$ milk and add to the blots.

i. Lab will record the dilution factor of the secondary antibody.

e. Incubate at room temperature for $1 \mathrm{hr}$.

f. Wash the blots with TBS $+0.5 \%$ Tween-20 four times for $15 \mathrm{~min}$ each.

8. \#Developing:
a. Remove as much wash buffer as possible.
b. Mix Super Signal West Pico Chemiluminescent Substrate solutions in equal proportions and add it to the blot.
c. Incubate for $\sim 1 \mathrm{~min}$.
$\mathrm{d}$. Insert the blot in the developing cassette and develop the blot in the dark. 
e. Expose the blot to the film at three time points, starting with $15 \mathrm{~s}$. Determine the other two time points based on the strength of the signal in the $15 \mathrm{~s}$ exposure.

9. \#Scan film and quantify band intensity using densitometric analysis software.

10. Repeat independently two additional times.

\section{Deliverables}

- Data to be collected:

1. Images of probed membranes (images of full films with molecular weight ladders).

2. Scanned image of Ponceau-stained membranes after protein transfer.

3. Quantified signal intensities and bar graphs of mean signal intensities normalized for $\beta$-tubulin loading and total pan-protein levels.

\section{Confirmatory analysis plan}

- Statistical analysis of the Replication Data:

1. For each cell line compare the following normalized phosphorylated kinase levels of primary kinase inhibitor alone, primary kinase inhibitor + ligand, and primary kinase inhibitor + ligand + secondary kinase inhibitor.

- One-way ANOVA.

- Note: at the time of analysis, we will generate a histogram of all the data to determine if it follows a Gaussian distribution or not. If it is skewed, we will perform the appropriate transformation in order to proceed with the proposed statistical analysis.

- Meta-analysis of original and replication attempt effect sizes:

1. We will plot the replication data (mean and $95 \%$ confidence interval) and will include the original data point, calculated directly from the representative image in Figure $2 \mathrm{C}$, as a single point on the same plot for comparison.

\section{Known differences from the original study}

- We are including three additional control conditions;

1. Media alone.

i. To provide a baseline.

2. Treatment of the cells with the secondary kinase inhibitor alone.

i. To assess any effects, the secondary kinase inhibitor may be independent of the ligand and primary kinase inhibitor.

3. Treatment of a control cell line with the growth factor ligand alone.

i. To ensure the growth factor ligand is active.

- FGF should cause phosphorylation of ERK1/2 in HL60 cells.

- NRG1 should cause phosphorylation of HER3 in MCF7 cells.

- HGF should cause phosphorylation of MET in HEK293 cells.

- The original authors recommended that the replicating lab follows a standard Western blot protocol.

Provisions for quality control

- All data obtained from the experiment-raw data, data analysis, control data and quality control data-will be made publicly available, either in the published manuscript or as an open access dataset available on the Open Science Framework (https://osf.io/h0pnz/). 
- Cell lines will be validated by STR profiling and screened for mycoplasma contamination.

- A lab from the Science Exchange network with extensive experience in conducting Western blot assays for phosphorylated proteins will perform these experiments.

\section{Power Calculations}

\section{Protocol 1}

The original data presented is qualitative (images of survival curves) and the authors were unable to share the raw data values with the RP:CB core team. To estimate original effect sizes, we determined approximate $\mathrm{IC}_{50}$ concentrations from the original survival curve images.

Summary of the original data.

\begin{tabular}{lc} 
A204 cells & IC $_{50}$ \\
\hline Sunitinib & $0.05 \mu \mathrm{M}$ \\
\hline Sunitinib + FGF & $2.5 \mu \mathrm{M}$ \\
\hline Sunitinib + FGF + PD173074 & $0.025 \mu \mathrm{M}$ \\
\hline - FGF induces resistance to Sunitinib. & \\
- PD173074 blocks FGF-induced resistance to Sunitinib, restoring sensitivity.
\end{tabular}

\begin{tabular}{lc} 
M14 & IC $_{50}$ \\
\hline PLX4032 & $0.1 \mu \mathrm{M}$ \\
\hline PLX4032 + NRG1 & $0.2 \mu \mathrm{M}$ \\
\hline PLX4032 + NRG1 + Lapatinib & $0.1 \mu \mathrm{M}$ \\
\hline - NRG1 induces partial resistance to PLX4032. & \\
- Lapatinib blocks NRG1-induced resistance to PLX4032, restoring sensitivity.
\end{tabular}

\begin{tabular}{lc} 
KHM-3S & IC $_{50}$ \\
\hline Erlotinib & $0.5 \mu \mathrm{M}$ \\
\hline Erlotinib + HGF & $>10 \mu \mathrm{M}$ \\
\hline Erlotinib + HGF + Crizotinib & $0.3 \mu \mathrm{M}$ \\
\hline - HGF induces resistance to Erlotinib. & \\
- Crizotinib blocks HGF-induced resistance to Erlotinib, restoring sensitivity.
\end{tabular}

We have calculated the projected sample size based on a variety of different possible levels of variance using a one-way ANOVA test with an alpha error of 0.05 .

- These power calculations were performed with G*Power software, version 3.1.7 (Faul et al., 2007).

- The F statistic was calculated at http://statpages.org/anova1sm.html.

- The $\eta_{\mathrm{p}}^{2}$ was calculated using the formula on the spreadsheet accessed from Lakens and colleagues (Lakens, 2013).

A204

\begin{tabular}{lcllll} 
Variance & $\mathbf{F}(\mathbf{2}, \mathbf{6})$ & $\eta_{\mathrm{P}}{ }^{2}$ & Effect size $\boldsymbol{f}$ & Power & Total sample size across all groups \\
\hline $2 \%$ & 7273.6132 & 0.999588 & 49.25631 & $99.99 \%$ & 6 \\
\hline $15 \%$ & 129.3087 & 0.977326 & 6.565316 & $99.99 \%$ & 6 \\
\hline $28 \%$ & 37.1103 & 0.925206 & 3.517109 & $98.53 \%$ & 6 \\
\hline $40 \%$ & 18.184 & 0.858384 & 2.461981 & $85.32 \%$ & 6
\end{tabular}

For each percent variance, the relative standard deviation of the approximated $\mathrm{IC}_{50}$ was used to calculate the $\mathrm{F}$ statistic from a one-way ANOVA analysis, which was converted to $\eta_{\mathrm{p}}{ }^{2}$ (the ratio of variance attributed to the effect and the effect plus its associate error variance from the ANOVA), and 
then used to determine the effect size (Cohen's $f$ ) and the needed sample size to obtain at least $80 \%$ power. The actual power obtained is listed.

M14

\begin{tabular}{lcllll}
\hline Variance & $\mathbf{F}(\mathbf{2}, \mathbf{6})$ & $\eta_{\mathrm{P}}{ }^{2}$ & Effect size $\boldsymbol{f}$ & Power & Total sample size across all groups \\
\hline $\mathbf{2 \%}$ & 1250 & 0.997606 & 20.4135 & $99.99 \%$ & 6 \\
\hline $15 \%$ & 22.2222 & 0.881057 & 2.721652 & $90.90 \%$ & 6 \\
\hline $28 \%$ & 6.3776 & 0.680089 & 1.458036 & $85.39 \%$ & 9 \\
\hline $40 \%$ & 3.125 & 0.510204 & 1.020621 & $88.33 \%$ & 15
\end{tabular}

KHM-S3

\begin{tabular}{lrllll}
\hline Variance & $\mathbf{F}(\mathbf{2}, \mathbf{6})$ & $\eta_{\mathbf{P}}{ }^{2}$ & Effect size $\boldsymbol{f}$ & Power & Total sample size across all groups \\
\hline $2 \%$ & 6890.8212 & 0.999565 & 47.9359 & $99.99 \%$ & 6 \\
\hline $15 \%$ & 122.5035 & 0.976096 & 6.390149 & $99.99 \%$ & 6 \\
\hline $28 \%$ & 35.1573 & 0.921378 & 3.423315 & $98.12 \%$ & 6 \\
\hline $40 \%$ & 17.2271 & 0.851684 & 2.396322 & $83.59 \%$ & 6 \\
\hline
\end{tabular}

In order to produce quantitative replication data, we will run the experiment three times. Each time we will quantify the $I C_{50}$. We will determine the standard deviation of the $I C_{50}$ across the three biological replicates and combine this with the means from the original study to simulate an effect size. Using this simulated effect size, we will then determine the number of replicates necessary to reach a power of at least $80 \%$. We will then perform additional replicates, if required, to ensure that the experiment has more than $80 \%$ power to detect the original effect.

\section{Protocol 2}

The original data presented is qualitative (images of Western Blots). We used Image Studio Lite v. 4.0.21 (LICOR) to perform densitometric analysis of the presented bands to quantify the original effect size. Levels of phospho-protein were normalized to total protein and then normalized to the control.

Summary of original data.

\begin{tabular}{lllll} 
A204 cells & PPDGFR & PAKT & PERK & PFRS2 \\
\hline Control & 1 & 1 & 1 & 1 \\
\hline Sunitinib alone & 0.264 & 0.0845 & 1.952 & 1.473 \\
\hline Sunitinib + FGF & 0.337 & 0.092 & 5.350 & 8.069 \\
\hline Sunitinib + FGF + PD173074 & 0.304 & 0.071 & 0.369 & 1.013
\end{tabular}

- FGF activates pFRS2 and pERK in the presence of Sunitinib.

- PD173074 blocks FGF-induced pFRS2 and pERK activation.

\begin{tabular}{llll} 
M14 cells & pHER3 & PAKT & pERK \\
\hline Control & 1 & 1 & 1 \\
\hline PLX4032 alone & 0.3667 & 1.8645 & 0.0524 \\
\hline PLX4032 + NRG1 & 3.9447 & 11.211 & 0.0539 \\
\hline PLX4032 + NRG1 + Lapatinib & 1.0666 & 1.7863 & 0.0571
\end{tabular}

- NRG1 activates pHER3 and PAKT in the presence of PLX4032.

- Lapatinib blocks NRG1-induced pHER3 and pAKT activation.

\begin{tabular}{lllll} 
KHM-3S cells & pEGFR & PAKT & pERK & PMET \\
\hline Control & 1 & 1 & 1 & 1 \\
\hline Erlotinib alone & 0.008 & 0.609 & 0.18 & 1.098
\end{tabular}

Table 10. Continued on next page 
Table 10. Continued

\begin{tabular}{lllll} 
KHM-3S cells & pEGFR & PAKT & PERK & PMET \\
\hline Erlotinib + HGF & 0.014 & 1.381 & 0.979 & 11.66 \\
\hline Erlotinib + HGF + Crizotinib & 0.023 & 0.417 & 0.085 & 1.095
\end{tabular}

- HGF activates PMET and pERK in the presence of Erlotinib.

- Crizotinib blocks HGF-induced pMET and pERK activation.

We have calculated the projected sample size based on a variety of different possible levels of variance (Koller and Wätzig, 2005) using a one-way ANOVA test with an alpha error of 0.05 .

- These power calculations were performed with G*Power software, version 3.1.7 (Faul et al., 2007).

- The F statistic was calculated at http://statpages.org/anova1sm.html.

- The $\eta_{\mathrm{p}}^{2}$ was calculated using the formula on the spreadsheet accessed from Lakens and colleagues (Lakens, 2013).

\begin{tabular}{|c|c|c|c|c|}
\hline $2 \%$ Variance & pPDGFR & pAKT & pERK & pFRS2 \\
\hline$F(3,8)$ & 2884.5133 & 6189.0064 & 4400.8341 & 5183.0738 \\
\hline$\eta_{p}^{2}$ & 0.999076377 & 0.999569314 & 0.999394421 & 0.999485769 \\
\hline Effect size $f$ & 32.8891 & 48.17548 & 40.62403 & 44.08686 \\
\hline Power & $99.99 \%$ & $99.99 \%$ & $99.99 \%$ & $99.99 \%$ \\
\hline Total sample size across all groups & 8 & 8 & 8 & 8 \\
\hline $15 \%$ variance & PPDGFR & pAKT & pERK & pFRS2 \\
\hline$F(3,8)$ & 51.28023644 & 110.0267804 & 78.23705067 & 92.14353422 \\
\hline$\eta_{p}^{2}$ & 0.950568679 & 0.976336986 & 0.967039009 & 0.971873631 \\
\hline Effect size $f$ & 4.385212 & 6.423398 & 5.416539 & 5.87825 \\
\hline Power & $99.99 \%$ & $99.99 \%$ & $99.99 \%$ & $99.99 \%$ \\
\hline Total sample size across all groups & 8 & 8 & 8 & 8 \\
\hline $28 \%$ variance & PPDGFR & pAKT & pERK & pFRS2 \\
\hline$F(3,8)$ & 14.71690459 & 31.57656327 & 22.4532352 & 26.44425408 \\
\hline$\eta_{p}^{2}$ & 0.846598456 & 0.922125726 & 0.893842473 & 0.908396348 \\
\hline Effect size $f$ & 2.349221 & 3.441106 & 2.901717 & 3.149063 \\
\hline Power & $91.97 \%$ & $99.79 \%$ & $98.43 \%$ & $99.35 \%$ \\
\hline Total sample size & 8 & 8 & 8 & 8 \\
\hline $40 \%$ variance & PPDGFR & pAKT & PERK & pFRS2 \\
\hline$F(3,8)$ & 7.21128325 & 15.472516 & 11.00208525 & 12.9576845 \\
\hline$\eta_{p}^{2}$ & 0.73003845 & 0.852988598 & 0.804907816 & 0.829326246 \\
\hline Effect size $f$ & 1.644455 & 2.408774 & 2.031202 & 2.204344 \\
\hline Power & $96.95 \%$ & $93.12 \%$ & $83.18 \%$ & $88.55 \%$ \\
\hline Total sample size across all groups & 12 & 8 & 8 & 8 \\
\hline
\end{tabular}

For each percent variance, the relative standard deviation of the approximated phospho-protein level was used to calculate the $F$ statistic from a one-way ANOVA analysis, which was converted to $\eta_{p}{ }^{2}$ (the ratio of variance attributed to the effect and the effect plus its associated error variance from the ANOVA), and then used to determine the effect size (Cohen's $f$ ) and the needed sample size to obtain at least $80 \%$ power. The actual power obtained is listed. 
M14 cells

\begin{tabular}{|c|c|c|c|}
\hline $2 \%$ Variance & pHER3 & PAKT & PERK \\
\hline$F(3,8)$ & 4297.4601 & 5283.2994 & 6645.7378 \\
\hline$\eta_{p}^{2}$ & 0.999379863 & 0.99949552 & 0.999598901 \\
\hline Effect size $f$ & 40.14408 & 44.51111 & 49.92144 \\
\hline Power & $99.99 \%$ & $99.99 \%$ & $99.99 \%$ \\
\hline Total sample size across all groups & 8 & 8 & 8 \\
\hline $15 \%$ variance & pHER3 & pAKT & PERK \\
\hline$F(3,8)$ & 76.39929067 & 93.92532267 & 118.1464498 \\
\hline$\eta_{p}^{2}$ & 0.966272885 & 0.972392466 & 0.977927341 \\
\hline Effect size $f$ & 5.352545 & 5.934812 & 6.656194 \\
\hline Power & $99.99 \%$ & $99.99 \%$ & $99.99 \%$ \\
\hline Total sample size across all groups & 8 & 8 & 8 \\
\hline $28 \%$ variance & pHER3 & pAKT & pERK \\
\hline$F(3,8)$ & 21.92581684 & 26.95560918 & 33.90682551 \\
\hline$\eta_{p}^{2}$ & 0.891565784 & 0.909977657 & 0.927087448 \\
\hline Effect size $f$ & 2.867435 & 3.179364 & 3.565818 \\
\hline Power & $98.24 \%$ & $99.42 \%$ & $99.88 \%$ \\
\hline Total sample size & 8 & 8 & 8 \\
\hline $40 \%$ variance & pHER3 & рAKT & PERK \\
\hline$F(3,8)$ & 10.74365025 & 13.2082485 & 16.6143445 \\
\hline$\eta_{p}^{2}$ & 0.801148125 & 0.8320201 & 0.861694667 \\
\hline Effect size $f$ & 2.007204 & 2.225555 & 2.496073 \\
\hline Power & $82.32 \%$ & $89.11 \%$ & $94.57 \%$ \\
\hline Total sample size across all groups & 8 & 8 & 8 \\
\hline
\end{tabular}

KHM-S3 cells

\begin{tabular}{|c|c|c|c|c|}
\hline $2 \%$ Variance & pEGFR & pAKT & PERK & PMET \\
\hline$F(3,8)$ & 7271.894 & 1594.1561 & 3697.7822 & 6041.5258 \\
\hline$\eta_{p}^{2}$ & 0.999633426 & 0.998330017 & 0.999279367 & 0.999558805 \\
\hline Effect size $f$ & 52.22032 & 24.45012 & 37.238 & 47.59802 \\
\hline Power & $99.99 \%$ & $99.99 \%$ & $99.99 \%$ & $99.99 \%$ \\
\hline Total sample size across all groups & 8 & 8 & 8 & 8 \\
\hline $15 \%$ variance & pEGFR & pAKT & PERK & PMET \\
\hline$F(3,8)$ & 129.2781156 & 28.34055289 & 65.73835022 & 107.4049031 \\
\hline$\eta_{p}^{2}$ & 0.979789525 & 0.913998523 & 0.961016505 & 0.975773338 \\
\hline Effect size $f$ & 6.962707 & 3.260016 & 4.965066 & 6.346404 \\
\hline Power & $99.99 \%$ & $99.57 \%$ & $99.99 \%$ & $99.99 \%$ \\
\hline Total sample size across all groups & 8 & 8 & 8 & 8 \\
\hline $28 \%$ variance & pEGFR & pAKT & PERK & PMET \\
\hline$F(3,8)$ & 37.1015 & 8.13344949 & 18.86623571 & 30.82411122 \\
\hline$\eta_{p}^{2}$ & 0.932944692 & 0.753089075 & 0.876158512 & 0.920376091 \\
\hline Effect size $f$ & 3.730022 & 1.746437 & 2.659857 & 3.399859 \\
\hline Power & $99.94 \%$ & $98.31 \%$ & $96.62 \%$ & $99.75 \%$ \\
\hline Total sample size across all groups & 8 & 12 & 8 & 8 \\
\hline
\end{tabular}

Table 12. Continued on next page 
Table 12. Continued

\begin{tabular}{lllll}
$\mathbf{4 0} \%$ variance & pEGFR & pAKT & pERK & pMET \\
\hline $\mathrm{F}(3,8)$ & 18.179735 & 3.98539025 & 9.2444555 & 15.1038145 \\
\hline$\eta_{\mathrm{p}}{ }^{2}$ & 0.872080242 & 0.59912149 & 0.776119611 & 0.84993841 \\
\hline Effect size $f$ & 2.611015 & 1.222506 & 1.8619 & 2.379901 \\
\hline Power & $96.09 \%$ & $94.83 \%$ & $99.19 \%$ & $92.58 \%$ \\
\hline Total sample size across all groups & 8 & 16 & 12 & 8
\end{tabular}

In order to produce quantitative replication data, we will run the experiment three times. Each time we will quantify band intensity. We will determine the standard deviation of band intensity across the three biological replicates and combine this with the mean from the original study to simulate the original effect size. We will use this simulated effect size to determine the number of replicates necessary to reach a power of at least $80 \%$. We will then perform additional replicates, if required, to ensure that the experiment has more than $80 \%$ power to detect the original effect.

\section{Acknowledgements}

The Reproducibility Project: Cancer Biology core team would like to thank the original authors, in particular Dr Jeff Settleman, for generously sharing critical information to ensure the fidelity and quality of this replication attempt. We would also like to thank the following companies for generously donating reagents to the Reproducibility Project: Cancer Biology: American Type Culture Collection (ATCC), BioLegend, Charles River Laboratories, Corning Incorporated, DDC Medical, EMD Millipore, Harlan Laboratories, LI-COR Biosciences, Mirus Bio, Novus Biologicals, and Sigma-Aldrich.

\section{Additional information}

Group author details

\section{Reproducibility Project: Cancer Biology}

Elizabeth lorns: Science Exchange, Palo Alto, United States; William Gunn: Mendeley, London, United Kingdom; Fraser Tan: Science Exchange, Palo Alto, United States; Joelle Lomax: Science Exchange, Palo Alto, United States; Timothy Errington: Center for Open Science, Charlottesville, United States

Competing interests

EG: The Monoclonal Antibody Core Facility is a Science Exchange associated laboratory. RP:CB: EI, FT and JL are employed and holds shares in Science Exchange Inc. The other authors declare that no competing interests exist.

Funding

\begin{tabular}{ll} 
Funder & Author \\
\hline Laura and John Arnold Foundation & Reproducibility Project: Cancer Biology
\end{tabular}

The Reproducibility Project: Cancer Biology is funded by the Laura and John Arnold Foundation, provided to the Center for Open Science in collaboration with Science Exchange. The funder had no role in study design or the decision to submit the work for publication.

Author contributions

EG, EG, Drafting or revising the article; RP:CB, Conception and design, Drafting or revising the article

\section{References}

Camidge DR, Pao W, Sequist LV. 2014. Acquired resistance to TKls in solid tumours: learning from lung cancer. Nature Reviews. Clinical Oncology 11:473-481. doi: 10.1038/nrclinonc.2014.104.

Chambers AF. 2009. MDA-MB-435 and M14 cell lines: identical but not M14 melanoma? Cancer Research 69:5292-5293. doi: 10.1158/0008-5472.CAN-09-1528. 
Chen YF, Fu LW. 2011. Mechanisms of acquired resistance to tyrosine kinase inhibitors. Acta Pharmaceutica Sinica $B$ 1:197-207. doi: 10.1016/j.apsb.2011.10.007.

Faul F, Erdfelder E, Lang AG, Buchner A. 2007. G* Power 3: A flexible statistical power analysis program for the social, behavioral, and biomedical sciences. Behavior Research methods 39:175-191. doi: 10.3758/BF03193146.

Gainor JF, Shaw AT. 2013. Emerging paradigms in the development of resistance to tyrosine kinase inhibitors in lung Cancer. Journal of Clinical Oncology 31:3987-3996. doi: 10.1200/JCO.2012.45.2029.

Garrett JT, Arteaga CL. 2011. Resistance to HER2-directed antibodies and tyrosine kinase inhibitors: mechanisms and clinical implications. Cancer Biology \& Therapy 11:793-800. doi: 10.4161/cbt.11.9.15045.

Harbinski F, Craig VJ, Sanghavi S, Jeffery D, Liu L, Sheppard KA, Wagner S, Stamm C, Buness A, ChatenayRivauday C, Yao Y, He F, Lu CX, Guagnano V, Metz T, Finan PM, Hofmann F, Sellers WR, Porter JA, Myer VE, Graus-Porta D, Wilson CJ, Buckler A, Tiedt R. 2012. Rescue screens with secreted proteins reveal compensatory potential of receptor tyrosine kinases in driving cancer growth. Cancer Discovery 2:948-959. doi: 10.1158/21598290.CD-12-0237.

Holliday DL, Speirs V. 2011. Choosing the right cell line for breast cancer research. Breast Cancer Research 13:215. doi: 10.1186/bcr2889.

Koller A, Wätzig H. 2005. Precision and variance components in quantitative gel electrophoresis. Electrophoresis 26:2470-2475. doi: 10.1002/elps.200500024.

Krejci P, Faitova J, Laurell H, Hampl A, Dvorak P. 2003. FGF-2 expression and its action in human leukemia and lymphoma cell lines. Leukemia 17:818-820. doi: 10.1038/sj.leu.2402861.

Lakens D. 2013. Calculating and reporting effect sizes to facilitate cumulative science: a practical primer for t-tests and ANOVAs. Frontiers in Psychology 4:863. doi: 10.3389/fpsyg.2013.00863.

Mok TS, Wu YL, Thongprasert S, Yang CH, Chu DT, Saijo N, Sunpaweravong P, Han B, Margono B, Ichinose Y, Nishiwaki Y, Ohe Y, Yang JJ, Chewaskulyong B, Jiang H, Duffield EL, Watkins CL, Armour AA, Fukuoka M. 2009. Gefitinib or Carboplatin-Paclitaxel in pulmonary adenocarcinoma. The New England Journal of Medicine 361:947-957. doi: 10.1056/NEJMoa0810699.

Montero-Conde C, Ruiz-Llorente S, Dominguez JM, Knauf JA, Viale A, Sherman EJ, Ryder M, Ghossein RA, Rosen N, Fagin JA. 2013. Relief of feedback inhibition of HER3 transcription by RAF and MEK inhibitors attenuates their antitumor effects in BRAF-mutant thyroid carcinomas. Cancer Discovery 3:520-533. doi: 10.1158/2159-8290.CD-12-0531.

Nakade J, Takeuchi S, Nakagawa T. 2014. Triple inhibition of EGFR, Met, and VEGF suppresses regrowth of HGF-triggered, erlotinib-resistant lung cancer harboring an EGFR mutation. Journal of Thoracic Oncology 9:775-783. doi: 10.1097/JTO.0000000000000170.

Nakagawa T, Takeuchi S, Yamada T, Nanjo S. 2012. Combined therapy with mutant-selective EGFR inhibitor and Met kinase inhibitor for overcoming erlotinib resistance in EGFR-mutant lung cancer. Molecular Cancer Therapeutics 11:2149-2157. doi: 10.1158/1535-7163.MCT-12-0195.

Rae JM, Creighton CJ, Meck JM, Haddad BR, Johnson MD. 2007. MDA-MB-435 cells are derived from M14 melanoma cells-a loss for breast cancer, but a boon for melanoma research. Breast Cancer Research and Treatment 104:13-19. doi: 10.1007/s10549-006-9392-8.

Sarup J, Jin P, Turin L, Bai X, Beryt M, Brdlik C, Higaki JN, Jorgensen B, Lau FW, Lindley P, Liu J, Ni I, Rozzelle J, Kumari R, Watson SA, Zhang J, Shepard HM. 2008. Human epidermal growth factor receptor (HER-1:HER-3) Fc-mediated heterodimer has broad antiproliferative activity in vitro and in human tumor xenografts. Molecular Cancer Therapeutics 7:3223-3236. doi: 10.1158/1535-7163.MCT-07-2151.

Sequist LV, Waltman BA, Dias-Santagata D, Digumarthy S, Turke AB, Fidias P, Bergethon K, Shaw AT, Gettinger S, Cosper AK, Akhavanfard S, Heist RS, Temel J, Christensen JG, Wain JC, Lynch TJ, Vernovsky K, Mark EJ, Lanuti M, lafrate AJ, Mino-Kenudson M, Engelman JA. 2011. Genotypic and histological evolution of lung cancers acquiring resistance to EGFR inhibitors. Science Translational Medicine 3:75ra26. doi: 10.1126/ scitranslmed.3002003.

Straussman R, Morikawa T, Shee K, Barzily-Rokni M, Qian ZR, Du J, Davis A, Mongare MM, Gould J, Frederick DT, Cooper ZA, Chapman PB, Solit DB, Ribas A, Lo RS, Flaherty KT, Ogino S, Wargo JA, Golub TR. 2012. Tumour micro-environment elicits innate resistance to RAF inhibitors through HGF secretion. Nature 487:500-504. doi: 10.1038/nature11183.

Welti JC, Gourlaouen M, Powles T, Kudahetti SC. 2011. Fibroblast growth factor 2 regulates endothelial cell sensitivity to sunitinib. Oncogene 30:1183-1193. doi: 10.1038/onc.2010.503.

Wilson TR, Fridlyand J, Yan Y, Penuel E, Burton L, Chan E, Peng J, Lin E, Wang Y, Sosman J, Ribas A, Li J, Moffat J, Sutherlin DP, Koeppen H, Merchant M, Neve R, Settleman J. 2012. Widespread potential for growth-factor-driven resistance to anticancer kinase inhibitors. Nature 487:505-509. doi: 10.1038/nature11249.

Wright JW, Wilson WL, Wakeling V, Boydstun AS, Jensen A, Kawas L, Harding JW. 2012. The hepatocyte growth factor/c-Met antagonist, divalinal-angiotensin IV, blocks the acquisition of methamphetamine dependent conditioned place preference in rats. Brain Sciences 2:298-318. doi: 10.3390/brainsci2030298.

Yang SH. 2013. Molecular basis of drug resistance: epidermal growth factor receptor tyrosine kinase inhibitors and Anaplastic lymphoma kinase inhibitors. Tuberculosis and Respiratory Diseases 75:188-198. doi: 10.4046/ trd.2013.75.5.188. 